\title{
Peranan Penggunaan Agunan Di Bank Islam Hubungannya Dengan Sistem Operasional Perbankan Syariah Di Medan
}

\author{
Oleh: \\ Selamat Pohan \\ Dosen FAI UMSU Ketua Program Studi Bisnis dan Manajemen Syariah \\ (Email:selamet pohan@gmail.com)
}

Perbankan syariah atau perbankan Islam (al-Mashrafiyah al-Islamiyah) adalah suatu sistem manajemen perbankan yang pelaksanaannya berdasarkan hukum Islam (syariah). Pembentukan sistem ini berdasarkan adanya larangan dalam agama Islam untuk meminjamkan atau memungut pinjaman dengan mengunakan bunga pinjaman (riba), serta larangan untuk berinvestasi pada usahausaha berkategori terlarang (haram). Bagi kaum muslimin, kehadiran bank islam dapat memenuhi kebutuhan akan sebuah lembaga keuangan yang bukan hanya sebatas melayani secara ekonomi namun juga spiritual. Penelitian ini berupaya untuk menganalisis peranan penggunaan agunan yang diminta pihak bank islam pada nasabah yang ada di kota Medan dan hubungannya dengan sistem operasional yang dijalankan oleh perbankan Islam tersebut dalam memperoleh laba atau keuntungan. Hasil penelitian menunjukkan, berdasarkan analisis temuan yang ada bahwa pendapat nasabah dan ormas Islam di Medan tentang agunan yang diterapkan dalam sistem operasional perbankan syariah, kurang tepat karena tidak sesuai dengan tujuan bank islam jika harus di minta agunan dibawah pinjaman 20 juta-an. Dan sebagai solusi yang peneliti temukan dalam penelitian ini adalah agar bank meminta surat kuasa penjamin pinjaman, bukan minta jaminan agunan. Kemudian berdasarkan data wawancara yang peneliti lakukan tentang kedudukan hukum agunan menjadi bagian sistem operasional perbankan syariah, itu tidak melanggar, karena untuk menjaga tingkat kehati-hatian.

Kata Kunci: Agunan, Bank Islam, Sistem Operasional

\section{A. Pendahuluan}

Perbankan syariah atau perbankan Islam (al-Mashrafiyah alIslamiyah) adalah suatu sistem manajemen perbankan yang pelaksanaannya berdasarkan hukum Islam (syariah). Pembentukan sistem ini berdasarkan adanya larangan dalam agama Islam untuk meminjamkan atau memungut pinjaman dengan mengunakan bunga pinjaman (riba), serta larangan untuk berinvestasi pada usaha-usaha berkategori terlarang (haram). Bagi kaum muslimin, kehadiran bank islam dapat memenuhi kebutuhan akan sebuah lembaga keuangan yang bukan hanya sebatas melayani secara ekonomi namun juga spiritual.

Firman Allah swt, yaitu:

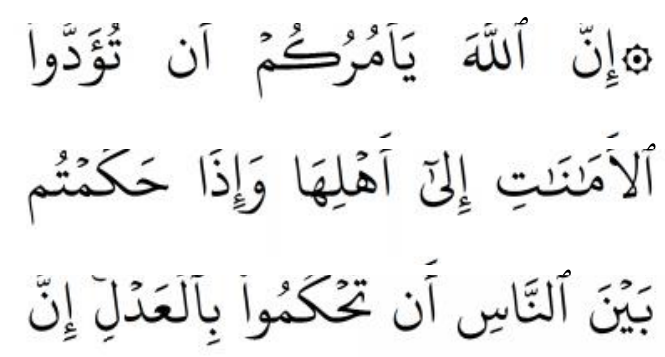



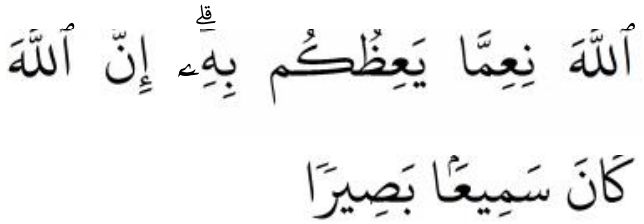

"Sesungguhnya Allah menyuruh kamu menyampaikan amanat kepada yang berhak menerimanya, dan (menyuruh kamu) apabila menetapkan hukum di antara manusia supaya kamu menetapkan dengan adil. ..."(QS. An-Nisa'/4:

$58)$.

Kemudian, Hadis riwayat Abu Daud nomor 3067, yaitu: ”Aku telah mendengar ayahku bahwa ia pernah mendengar Rasulullah shallallahu 'alaihi wasallam bersabda: "Tunaikanlah amanah kepada orang yang mempercayaimu dan janganlah engkau mengkhianati orang yang mengkhianatimu!" (HR. Abu Daud). Imam Hakim mengkategorikan hadis ini shahih). ${ }^{2}$

Bank Islam adalah sebagai sebuah alternatif lembaga jasa keuangan di samping perbankan konvensional yang telah lama ada. Ini terkait dengan tugas bank yang merupakan lembaga perantara jasa keuangan (financial intermediary), dengan tugas pokoknya menghimpun dana dari masyarakat, dan

\footnotetext{
${ }^{1}$ QS. An-Nisa'/4: 58

Karnaen Perwataatmadja., Muhammad Syafi'I Antonio, Apa dan Bagaimana Bank Islam (Yogyakarta: Dana Bhakti Prima Yasa, 1999), h. 17
}

diharapkan dengan dana yang dimaksud dapat memenuhi kebutuhan dana kredit atau pembiayaan yang tidak disediakan baik oleh pihak swasta maupun negara dalam upaya meningkatkan taraf hidup rakyat banyak. ${ }^{3}$ Peran bank sebagai perantara keuangan adalah mengambil posisi tengah di antara orang-orang atau pihak yang berlebihan dana (penyimpan, penabung, deposan) dan orangorang/pihak yang membutuhkan atau kekurangan dana (peminjam, debitor, investor). Allah swt berfirman, yaitu:

Artinya:

Dan jika (orang yang berhutang itu) dalam kesukaran, Maka berilah tangguh sampai dia berkelapangan. dan menyedekahkan (sebagian atau semua utang) itu, lebih baik bagimu, jika kamu Mengetahui. (QS. Al-Baqarah/2: 280).

Berdasarkan ayat tersebut, adalah sebuah kenyataan, kredit/pembiayaan kepada pengusaha kecil sangat tidak mungkin dilaksanakan dengan menggunakan Agunan. ${ }^{4}$ Berdasarkan konsep Bank Muamalat seyogianya menerapkan hal tersebut secara wajar. Ternyata bank muamalat berhasil, tidak saja

\footnotetext{
3 Muhammad, Manajemen Pembiayaan Bank Syariah (Yogyakarta: UPP AMP YMKN, 2005), h. 16.

${ }^{4}$ Ibrahim Lubis, Ekonomi Islam Suatu Pengantar-2 (Jakarta: Kalam Mulia, 1995), h. 74
} 
berhasil dalam menyalurkan dari $22 \%$ pembiayaan dalam bentuk KUK (Kredit Usaha Kecil), namun juga berhasil menekan kredit macet pada tingkat nol persen. Pembiayaan usaha kecil yang sudah dan akan dilaksnakan bank muamalat juga menggunakan dana sendiri tanpa bantuan pemerintah, yaitu sumber dana yang berasal dari nasabah tabungan-tabungan, deposan dan pemegang saham.

Muslehuddin,

mengemukakan 'karena sejak zaman dahulu, pemberi pinjaman tidak pernah lagi menaruh kepercayaan penuh kepada peminjam hanya berdasarkan perjanjian berdasarkan lisan, untuk itu harus ada tanggungan yang jelas yang dapat meringankan beban pemberi pinjaman apabila peminjam gagal memenuhi tanggung jawabnya'. Islam tidak memandang hina ide ini dan telah menetapkan prinsip yang luas terhadap pandangan ini. $^{5}$

Salah satu jenis pembiayaan yang dipraktikkan dalam perbankan syariah adalah pembiayaan mudharabah. Ia adalah pembiayaan yang disalurkan kepada pihak lain untuk suatu usaha yang produktif. Dalam pembiayaan ini bank berperan sebagai shahib al-maal (pemilik dana) yang membiayai $100 \%$ kebutuhan suatu usaha, sedangkan nasabah bertindak sebagai mudharib

\footnotetext{
${ }^{5}$ Muhammad Muslehuddin, Sistem Perbankan dalam Islam, (Jakarta: Rineka Cipta, 1994), h. 84
}

(pengelola dana). ${ }^{6}$ Dalam fatwa yang dikeluarkan oleh Dewan Syariah Nasional No. 07/DSN-MUI/IV/2000 dijelaskan bahwa pada prinsipnya dalam pembiayaan mudharabah tidak ada jaminan (agunan), namun agar mudharib tidak melakukan penyimpangan, bank dapat meminta jaminan (agunan) dari mudharib atau pihak ketiga, dan jaminan (agunan) ini hanya dapat dicairkan jika mudharib terbukti melakukan pelanggaran terhadap hal-hal yang telah disepakati. ${ }^{7}$ UU No. 10 Tahun 1998 pasal 8 menyatakan bahwa dalam menyalurkan dana, bank wajib mempunyai keyakinan atas kemampuan dan kesanggupan debitur untuk melunasi hutangnya sesuai dengan yang diperjanjikan.

Jika dianalisis fatwa yang dikeluarkan oleh Dewan Syariah Nasional No. 07/DSN-MUI/IV/2000, yaitu menjelaskan bahwa pada prinsipnya dalam pembiayaan mudharabah tidak ada jaminan (agunan). Maka berpijak dari kalimat fatwa DSN tersebut sangat tidak tepat jika bank islam sebagai pengguna sistem operasional perbankan syariah menggunakan agunan dalam segala pembiyaan. Calon peneliti memberikan argumentasi yang mendasar, yaitu tujuan bank islam adalah untuk

${ }^{6}$ Dewan Syariah Nasional Majelis Ulama Indonesia, Himpunan Fatwa Dewan Syariah Nasional. MUI; Edisi Revisi, (Jakarta: DSN-MUI, 2006) cet. keenam, h. 43

${ }^{7}$ Ibid. h. 44 


\section{Peranan Penggunaan Agunan Di Bank Islam Hubungannya Dengan Sistem Operasional Perbankan Syariah Di Medan ( Selamat Pohan)}

membantu memajukan pertumbuhan perekonomian ditengah-tengah kemiskinan umat (meningkatkan taraf hidup rakyat banyak ${ }^{8}$ ) terkhusus kepada perekonomian kaum dhuafa. Kemudian, jika diperhatikan rata-rata orang yang datang ke bank untuk meminjam dana dalam rangka memajukan pendapatan yang bersifat produktif semuanya adalah orangorang yang merasa kekurangan. Jika orang tersebut tidak merasa kekurangan rasanya tidak perlu orang untuk datang ke bank mengajukan pinjaman. Artinya tidaklah tepat jika segala sesuatu bentuk pengajuan pinjaman keperbankan syariah menggunakan agunan atau jaminan.

Alasannya mengapa agunan atau jaminan tidak tepat untuk digunakan? Karena, setiap orang yang datang untuk meminjam uang kebank karena ketiadaan harta, seandainya ada harta yang bisa dijadikan jaminan atau agunan berarti orang tersebut tergolong orang yang tidak perlu dibantu berdasarkan konsep Islam karena dianggap mampu. Apa bedanya bank konvensional dengan bank islam/syariah jika menggunakan agunan (jaminan)? Sangat zhalim menurut peneliti jika mudharib (pengelola dana) meminta agunan (jaminan) dengan alasan tidak adanya kepercayaan yang dianggap sebagai usaha tingkat kehati-hatian, dalam ajaran Islam hal ini dapat disebut sebagai ungkapan tidak amanah, sesuai firman Allah SWT di atas (QS. An-Nisa'/4: 58)

Berbagai macam faktor yang telah disebutkan, bahwa jaminan (agunan) bagi bank islam adalah suatu kebutuhan yang sangat sulit untuk diabaikan dalam menyalurkan pembiayaannya. Tanpa adanya jaminan (agunan), dengan kondisi bisnis yang penuh lika-liku, bank islam berada pada titik ketidakpastian. Terkait dengan fatwa yang dikeluarkan oleh Dewan Syariah Nasional dalam hal pembiayaan mudharabah, di mana di dalamnya terdapat statement tentang jaminan (agunan), tentunya bukan tanpa dasar dan alasan yang jelas. DSN berkewajiban untuk melahirkan fatwa-fatwa yang menjadi acuan dalam praktek ekonomi syariah di Indonesia. Karena DSN merupakan lembaga yang memiliki tugas untuk menumbuh-kembangkan penerapan nilai-nilai syariah dalam kegiatan perekonomian dan juga bertugas mengeluarkan fatwa atas jenis-jenis kegiatan keuangan syariah. Masalah yang timbul kemudian adalah hakikat mudharabah itu sendiri. Prinsip paling utama dalam pelaksanaan akad mudharabah adalah kepercayaan. Syafi'i Antonio menye- butnya dengan Trust

\footnotetext{
${ }^{8}$ Muhammad, Manajemen Pembiayaan, h. 16
} 
Financing. ${ }^{9} \quad$ Pada hakikatnya, seseorang yang meminjamkan hartanya atau memberikannya untuk dikelola orang lain adalah karena adanya kepercayaan. Dalam kaitannya pada praktik perbankan, mudharib berkedudukan sebagai seorang yang meminjam. Dengan adanya persyaratan jaminan (agunan), maka posisi calon mudharib ini menjadi sulit. Untuk itulah penulis merasa perlu untuk membahas mengenai bagaimana sebetulnya peranan kedudukan pengunaan jaminan (agunan) yang dipersyaratkan pada bank islam hubungannya dengan sistem operasional perbankan syariah di Medan.

\section{B. Tinjauan Literatur}

\section{A. Lembaga Bank Islam}

Bank islam merupakan lembaga keuangan yang menjadi salah satu pilihan masyarakat Indonesia. Bagi kaum muslimin, dapat dikatakan bahwa bank islam adalah suatu keharusan, dan bagi yang lain adalah alternative. Di satu sisi, sebagai lembaga keuangan yang melandaskan aktifitas operasionalnya pada prinsip syariah, bank islam mau tidak mau dituntut untuk mentaati ketentuan-ketentuan yang bersumber dari hukum-hukum

9 M. Syafi'i Antonio, Bank Syariah; Dari Teori ke Praktik (Jakarta: Gema Insani Press, 2001),cet. pertama, h. 98
Islam. Semua itu harus tetap diperhatikan dan dilaksanakan dengan baik. Di sisi lain, bank islam juga dihadapkan pada persaingan bisnis dengan perbankan konvensional yang tentunya lebih senior dalam hal keberadaan dan operasionalnya di tanah air ini. Beragam hal terkait perbankan konvensional membuat bank islam harus melakukan inovasi atau paling tidak menyamai aktifitas operasional bank konvensional, dengan catatan khusus: tidak diperkenankan untuk berbenturan dengan prinsip syariah.

Kondisi yang ada pada masyarakat Indonesia baik dari segi ekonomi, perkembangan teknologi, karakter, dan lainnya, melahirkan persoalan-persoalan yang kadang menghadapkan bank islam pada permasalahan penerapan prinsip syariah. Jika tidak ditangani dengan baik, baik secara teknis maupun legalitas hukum, kondisi ini akan membahayakan keberlangsungan bank islam itu sendiri.

Untuk itulah fatwa Dewan Syariah Nasional-Majelis Ulama Indonesia sangat diperlukan agar berjalannya operasional lembaga keuangan syariah dapat sesuai dengan apa yang diharapkan.

1. Konsep Jaminan dan Pembiayaan Mudharabah Shahib al-maal (pemilik dana) membiayai $100 \%$ 
kebutuhan suatu usaha, sedangkan nasabah bertindak sebagai mudharib (pengelola dana). ${ }^{10}$ Dalam Islam, prinsip paling utama dalam pelaksanaan akad mudharabah adalah kepercayaan.

2. Penjelasan Fatwa DSN-MUI No. 07/DSN-MUI/IV/2000 Dalam fatwa yang dikeluarkan oleh Dewan Syariah Nasional No. 07/DSN-MUI/IV/2000

dijelaskan bahwa pada prinsipnya dalam pembiayaan mudharabah tidak ada agunan, namun agar mudharib tidak melakukan penyimpangan, bank dapat meminta jaminan dari mudharib atau pihak ketiga, dan jaminan ini hanya dapat dicairkan jika mudharib terbukti melakukan pelanggaran terhadap hal-hal yang telah disepakati. ${ }^{11}$

3. Analisa Fatwa DSN-MUI tentang Jaminan Pembiayaan Mudharabah Dalam menganalisa fatwa DSN MUI tentang Jaminan Pembiayaan Mudharabah ini penulis melakukan pendekatan tujuan bank Islam untuk mengetahui kedudukan hukum agunan

${ }^{10}$ Dewan Syariah Nasional Majelis Ulama Indonesia, Himpunan Fatwa, h. 43

${ }^{11}$ Ibid, h. 44 pada pembiayaan mudharabah, dengan sebelumnya menganalisis faktor-faktor dipersyaratkannya jaminan pada pembiayaan mudharabah.

\section{B. Konsep Agunan berdasar} kajian-kajian

Ada beberapa kajian-kajian persoalan tentang agunan, diantaranya yaitu:

1. Penelitian tentang agunan yang berkaitan dengan pemberian bantuan pembiayaan, diantaranya oleh Irawati (2007), dengan mengangkat judul "Aplikasi Agunan dalam Pembiayaan Mudharabah dan Murabahah (Studi Kasus PT. Bank Muamalat Indonesia, Tbk.)." Penelitian ini membahas mengenai aplikasi agunan dalam pembiayaan mudharabah dan murabahah. Tinjauannya adalah pada teknis operasional pembiayaan mudharabah dan murabahah di PT. Bank Muamalat Indonesia, Tbk. Bank Muamalat Indonesia terlebih dahulu memperhatikan situasi dan kondisi calon nasabah pembiayaan dengan analisa pembiayaan. Dari mulai analisa proposal pembiayaan, 


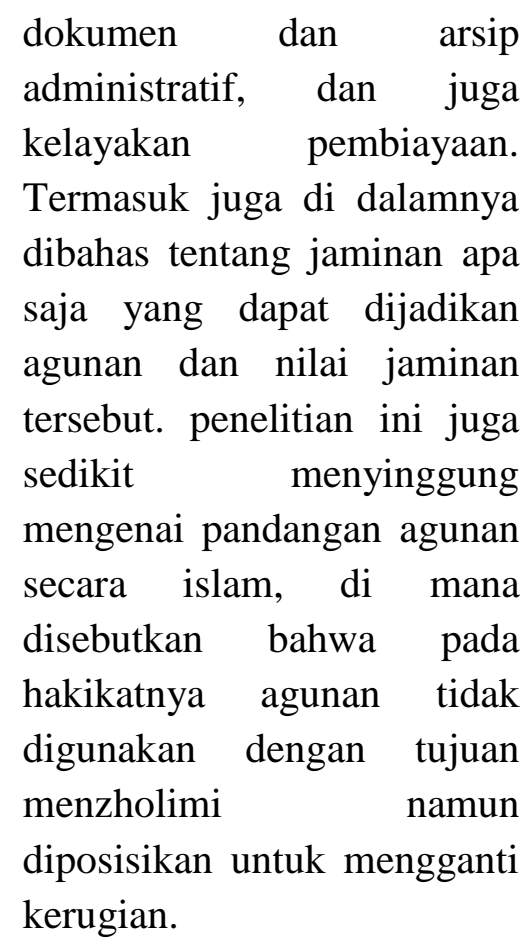

2. Tinjauan Hukum Islam Terhadap penggunaan Agunan Bagi Nasabah Dari Perusahaan Asuransi yang Pailit, oleh Tita Ritawaty (2004).

Penelitian ini menjelaskan mengenai dasar hukum penentuan seseorang atau badan usaha yang dinyatakan jatuh pailit, penetapan seseorang atau badan usaha yang dinyatakan jatuh pailit, keterkaitannya dengan status hukum agunan. Analisa terhadap Agunan bagi nasabah dari perusahaan asuransi yang pailit, berdasarkan dalil-dalil dari Al-Qur'an maupun Hadis, dan pendapat ulama menyatakan agunan tidak dapat diambil sekalipun

nasabah tidak sanggup untuk mengembalikan hutangnya.

Kedua penelitian di atas membahas mengenai agunan yang diterapkan pada lembaga keuangan tertentu. Peneliti pertama lebih menekankan pembahasan pada tataran aplikasi dan teknis manajemen pembiayaan. Yang lebih ditampilkan adalah aplikasi pembiayaan dan strategi pengembangan penerapan agunan.

Terlihat pada peneliti kedua, lebih khusus membahas agunan dalam tinjauan hukum Islam. Banyak dalil Al-Qur'an, Hadis, dan juga pendapat ulama yang disampaikan, yaitu ulama menyatakan agunan tidak dapat diambil sekalipun nasabah tidak sanggup untuk mengembalikan hutangnya.

\section{Konsep Kegunaan Agunan}

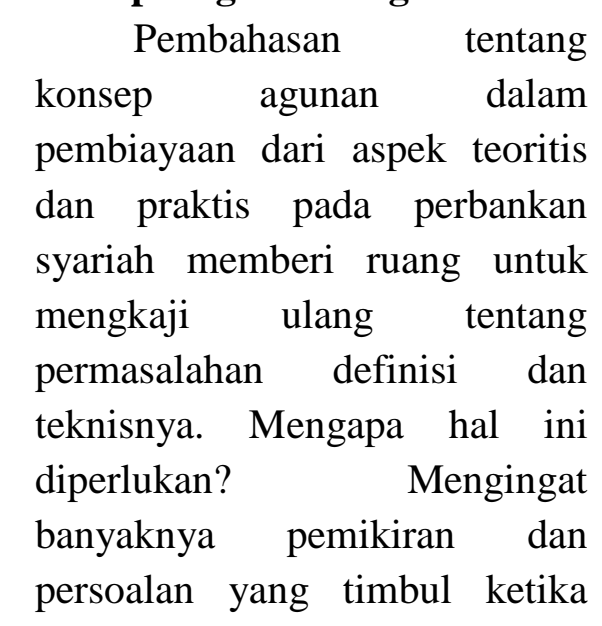




\section{Peranan Penggunaan Agunan Di Bank Islam Hubungannya Dengan Sistem Operasional Perbankan Syariah Di Medan ( Selamat Pohan)}

sesuatu pembiayaan dilakukan oleh pihak perseorangan atau pihak perbankan. Hal ini dapat di lihah salah satu dilemah yang muncul kepermukaan, yaitu:

Pembiayaan mudharabah didefinisikan oleh para fuqa sebagai kerjasama dua pihak dengan mempertemukan modal dan tenaga secara langsung serta membagi keuntungan secara bersama sama dan membebankan kerugian kepada penyedia modal ini bergeser menjadi kerjasama yang melibatkan tiga pihak ,pemilik modal pengusaha dan bank. Perbedaan makna tersebut berakibat implikasi yang berbeda pada dataran tersebut teknis oprasional mudharabah ditandai dengan penentuan pembagian keuntungan yang melibatkan tiga pihak yang akhirnya secara otomatis menetapkan agunan sebagai jaminan. Sementara itu beberapa ketentuan tersebut ditingalkan bank yang menjadi tumpuan berlangsungnya interaksi ekonomi masyarakat modern. ${ }^{12}$ Permasalahan ini memberikan gambaran, seakanakan agunan merupakan kata

12 Djoko Purnotomo. 2008. Jaminan Berupa Agunan dalam Bank Syariah ( Analisis Asas Kemaslahatan Pasal 8 UU No. 10 Tahun 1998 tentang Perbankan). Thesis, UIN Sunan Kalijaga Yogyakarta. kunci untuk dijadikan solusi pada kegiatan pembiayaan, baik secara lembaga maupun individu. Sehinngga tingkat maslahah jadi terabaikan, dan lebih berorientasi pada hanya profit.

Walaupun agunan menurut undang-undang Republik Indonesia Nomor 21 tahun 2008 tentang perbankan syariah pasal 26, yaitu: Agunan adalah jaminan tambahan, baik berupa benda bergerak maupun benda tidak bergerak yang diserahkan oleh pemilik agunan kepada bank syariah dan/atau UUS, guna menjamin pelunasan kewajiban nasabah penerima fasilitas. ${ }^{13}$ Artinya agunan bukanlah hal yang mutlak untuk diberlakukan. Senada dengan program pemerintah yang berkaitan dengan Peraturan Menteri Koordinator Bidang Perekonomian nomor 8 Tahun 2015 tentang Pedoman Pelaksanaan KUR. Pada pasal 10 dibagian 4 agunan KUR adalah usaha yang dibiayai. ${ }^{14}$

\footnotetext{
13 Undang-Undang Republik Indonesia Nomor 21 tahun 2008 tentang perbankan syariah. (2008), h. 7

${ }^{14}$ Peraturan Menteri Koordinator Bidang Perekonomian nomor 8 Tahun 2015 tentang Pedoman Pelaksanaan KUR
} 
Secara umum ada beberapa bank syariah yang telah memperaktekan kredit tanpa agunan, yaitu:

1. Bank Syariah Danamon, dengan gamblang menawarkan produk kredit tanpa agunan (KTA) syariah ke nasabah. UUS Danamon sebenarnya memiliki produk pembiayaan kepada koperasi karyawan, dimana koperasi harus mengajukan proposal pembiayaan, laporan keuangan, hasil rapat akhir tahun, dan beberapa persyaratan lainnya, yang tak mengharuskan adanya jaminan fisik berupa barang. Direktur Syariah Danamon, Herry Hykmanto, mengatakan saat ini pihaknya fokus pada pembiayaan usaha kecil menengah dan produktif. "Tidak ada produk KTA syariah di UUS Danamon."

Product Management Head UUS Danamon, Puti Nurulharni, menambahkan produk pembiayaan kepada koperasi karyawan menerapkan persyaratan yang begitu ketat untuk dipenuhi, sehingga walau tak ada agunan barang secara fisik pembiayaannya terbilang cukup aman.
2. BNI syariah, memiliki produk pembiayaan tanpa mensyaratkan agunan barang fisik, melalui produk Hasanah Card. Persyaratannya pun cukup mudah, yaitu fotokopi identitas dan bukti penghasilan (slip gaji). Direktur Bisnis BNI Syariah, Imam T Saptono, mengatakan secara umum ada dua hal yang menjadi pertimbangan BNI Syariah saat mengeluarkan produk Hasanah Card, yaitu strategi pemasaran dan alasan bisnis. Imam menjelaskan dari aspek marketing, kartu pembiayaan atau kartu kredit (konvensional) adalah salah satu ikon produk perbankan yang menunjukan modernitas, progresif dan memiliki emotional

bonding yang cukup kuat dengan penggunanya. "Kami meyakini bahwa pasar perbankan syariah 510 tahun ke depan akan didominasi oleh kelompok muda, produktif dan dari kalangan middle class. Oleh karenanya kami yakin produk Hasanah Card adalah produk yang dapat membawa wajah BNI Syariah secara keseluruhan sebagai bank syariah yang 


\section{Peranan Penggunaan Agunan Di Bank Islam Hubungannya Dengan Sistem Operasional Perbankan Syariah Di Medan ( Selamat Pohan)}

modern, energik dan tetap peduli terhadap penerapan nilai-nilai syariah," papar Imam. Wacana adalah bagian dari wacana yang berkembang dalam masyarakat sehingga untuk meneliti perlu dilakukan analisis intlektual berkaitan dengan agunan tersebut. Perlu diteliti bagaimana tentang suatu hal diproduksi dan dikontruksikan dalam masyarakat. (Eriyanto, 2001:271).

\section{Metode Penelitian}

Penelitian ini menggunakan metode penelitian deskriptif dengan analisis tabel tunggal dan kualitatif. Tujuannya adalah untuk menggambarkan atau memaparkan keadaan sesuai dengan kenyataan atau dengan apa adanya. Penelitian ini juga bertujuan untuk melukiskan secara sistematis fakta atau karakteristik populasi tertentu atau bidang tertentu secara faktual dan cermat (Rakhmat, 2001:22).

Kick dan Miller (Moleong, 2006: 6) mendefinisikan bahwa penelitian kualitatif adalah tradisi tertentu dalam ilmu pengetahuan sosial yang secara fundamental bergantung pada pengamatan pada manusia dalam kawasannya sendiri dan berhubungan dengan orangorang tersebut dalam bahasanya dan dalam peristilahannya.
Analisis kualitatif adalah fokusnya pada penunjukkan makna, deskripsi, penjernihan dan penempatan data pada konteksnya masing-masing, dan seringkali melukiskannya di dalam kata-kata dari pada angka-angka. Data perlu disusun kedalam pola tertentu, kategori tertentu, fokus tertentu, tema tertentu atau pokok permasalahan tertentu. Karenanya, setiap catatan harian yang dihasilkan dalam pengumpulan data, apakah hasil wawancara atau hasil observasi, perlu direduksi dan dimasukkan kedalam pola, kategori, fokus, atau tema tertentu yang sesuai, dan akhirnya peneliti dapat mengambil kesimpulan-kesimpulan tertentu dari hasil pemahaman dan pengertiannya (Faisal, 2003:256).

\section{E. Hasil Penelitian}

Berdasarkan Analisa Data Tentang Peranan Penggunaan Agunan Hubungannya dengan Sistem Operasional Bank syariah, terkait hal tersebut dapat disimak secara hikmad tentang hasil penelitian yang dimaksudkan terlihat lebih lanjut.

Mengenai sikap para nasabah, dewasa ini terlihat ada dua kecenderungan, sikap pertama merasa tak perduli, apakah mereka selaku nasabah dibank syariah sudah pada jalan yang benar. Dan sikap kedua adalah memiliki rasa kepedulian dalam menentukan 
pilihan tentang eksistensi bank tersebut.

Berdasarkan angket yang telah disebarkan kepada responden tentang persoalan agunan, yaitu: Ketika melakukan pinjaman kebank syariah agunan bukan menjadi ketentuan. Berdasarkan jawaban responden $53 \%$ responden dari 100 nasabah sangat setuju bahwa ketika melakukan pinjaman tidak harus menggunakan agunan., dan di tambah $44 \%$ responden lagi yang menyatakan setuju. Jadi yang menyatakan kurang setuju ada $2 \%$ responden, sementara yang tidak setuju hanya $1 \%$ responden. Sesuai data yang diperoleh dilapangan melalui angket tersebut menunjukkan agunan masi mendapatkan perhatian dari masyarakat. Hal ini ditinjau berdasarkan antara 'sangat setuju' dengan 'setuju' ditotal 97\% yang menyatakan ketika melakukan pinjaman kebank syariah tidak harus ada agunan. Bila dianalisa hasilnya, keterkaitan responden sangat setuju dan setuju terlihat secara nyata: Jika pinjaman ke bank syariah berkisar dibawah 20 juta, tidak perlu pakai agunan.

Responden, dari 100 nasabah yang dijadikan sampel terlihat $43 \%$ sangat setuju bahwa pinjaman ke bank syariah berkisar dibawah 20 juta tidak perlu menggunakan agunan, dan yang menyatakan setuju ada 46\%. Ini menunjukkan masih tingginya keinginan nasabah atau masyarakat terhadap bank syariah untuk mendapatkan pinjaman tersebut.

Islam mengajarkan adanya kewajiban dakwah, maka tugas lembaga bank syariah dalam menjalankan sistem operasionalnya dengan kondisi di atas memiliki satu keterkaitan agar nasabah mendapatkan prioritas jika pinjaman hanya 20 juta kebawah, dan tidak perlu untuk mempertanyakan masalah agunan.

\section{1) Kejelasan Tujuan Bank Islam}

Perbankan syariah atau perbankan Islam (al-Mashrafiyah al-Islamiyah) adalah suatu sistem manajemen perbankan yang pelaksanaannya berdasarkan hukum Islam (syariah). Pembentukan sistem ini berdasarkan adanya larangan dalam agama Islam untuk meminjamkan atau memungut pinjaman dengan mengunakan bunga pinjaman (riba), serta larangan untuk berinvestasi pada usaha-usaha berkategori terlarang (haram). Bagi kaum muslimin, kehadiran bank islam dapat memenuhi kebutuhan akan sebuah lembaga keuangan yang bukan hanya sebatas melayani secara ekonomi namun juga spiritual, yaitu: Bank Islam Mampu Menciptakan masyarakat sebagai Pelaku Perubahan Sosial.

Jawaban responden terhadap kejelasan tujuan bank islam sebagai lembaga perbankan, 
bahwa bank islam mampu menjadi wadah pelaku perubahan sosial, $37 \%$ responden menjawab sangat setuju, 55\% respoden juga menyatakan setuju atas kemampuan untuk melakukan perubahan terhadap kehidupan nasabah. Dan syah-syah saja bila ada $8 \%$ anggapan bila bank islam tak mampu untuk menciptakan masyarakat yang berkemajuan dalam segi ekonomi, hal ini di dasarkan dengan adanya beberapa penomena ditengah masyarakat yang masi bersifat negatif. Contoh, Nasabah dianggap tidak patuh untuk memenuhi kewajiban jika tidak pakai agunan.

\section{2) Produk Perbankan Syariah}

Ada beberapa hal yang mesti menjadi perhatian bagi pengelola bank islam, bahwa pengelola dan pendiri harus mampu secara mandiri untuk mewujudkan yang hakiki konsep lembaga yang syariah, yaitu progresif dan transformatoris, agar umat islam secara komunal dapat menerima keberadaan konsep tersebut.

Fenomena ini, dapat dikaji berdasarkan pertanyaan, apakah nasabah mampu berperan untuk dapat mengambil alih fungsi melakukan tugas besar dalam menghilangkan sistem operasional pada bank syariah harus dengan agunan? Hal ini dapat dikaji melalui jawaban angket yang telah diberikan.

Setelah mencermati dengan jawaban responden atas sampel yang diajukan, ternyata nasabah begitu antusias merespon untuk berharap agar bank islam tidak menekankan persoalan agunan, ini terbukti sebanyak $58 \%$ responden sangat setuju dan $41 \%$ responden juga menyatakan setuju. Dan hanya $1 \%$ responden tidak setuju adanya penekanan harus ada agunan. Artinya dampak positif yang diharapkan nasabah menunjukkan tugas besar tersebut, dan ini semata-mata harus segera diwujudkan. Bank Islam Harus Mengagendakan untuk Menghilangkan Budaya: Setiap pengajuan pinjaman dibawah 20 juta dengan agunan.

\section{3) Hak Nasabah untuk \\ Mendapatkan bantuan}

Secara introvert (kedalam) nasabah dituntut untuk mampu menerima menangani masalah yang tambah kompleks. Hal ini yang menjadi salah satu masalah sehingga hak-hak nasabah menimbulkan kesan terlalu berlebihan, kemudian dilemah yang lain tidak terlepas dimana nasabah pernah gagal bekerjasama dengan pihak perbankan.

Satu hal yang menjadi masalah besar adalah munculnya gejolak bahwa bank islam, bagi nasabah yang tidak punya agunan 
maka pengajuan haknya untuk meminjam akan mengalami penyumbatan. Kondisi ini dapat dilihat berdasarkan jawaban responden yang telah disebarkan, yaitu: Bank Islam, belum Kompeten dalam Kehidupan Umat Islam, untuk mewujudkan hak nasabah.

Peran bank islam secara eklifisit, tidak berperan untuk menunjukkan kompetennya terhadap sesuatu yang telah diperbuat, karena akan menimbulkan kesan yang negatif. Sekalipun tidak terlalu tinggi persentasenya bila dilihat data yang ada $16 \%$ responden 'sangat setuju' bila dikatakan adanya kesombongan pada pihak perbankan islam dan disini menunjukkan tidak berkompetennya, ditambah lagi ada $31 \%$ 'setuju', namun tetap melahirkan penilaian masyarakat secara negatif. Walaupun $41 \%$ kurang setuju dan $12 \%$ tidak seetuju menerima dilemah yang berkembang dalam masyarakat.

\section{4) Kemampuan nasabah dalam memberikan agunan/jaminan.}

Ekses yang timbul dari ketidak mampuan calon nasabah memberikan agunan, ini mengakibatkan terjadinya perubahan prilaku pengerlola lembaga bank islam yang mengutamakan orang-orang yang bisa memberikan agunan jika dibandingkan dengan orang tidak punya kemampuan untuk memberikan agunan. Hal ini dapat disimak dari jawaban responden berikut; Agunan menjadi ketentuan penentu untuk pemberian bantuan dana.

Ketentuan di atas menunjukkan hampir semua responden memberikan jawaban bahwa lembaga bank islam menjadikan agunan sebagai penentu untuk pemberian bantuan/pinjaman, karena 100 responden yang menjadi sampel dari empat lembaga bank islam yang mewakili di Medan dengan total keseluruhan nasabah yaitu 4.435 orang. Maka dengan hal ini hanya 5 responden yang menyatakan 'kurang setuju' bahwa lembaga bank islam tidak mampu menerimah ketentuan tujuan hadirnya bank islam dikalangan umat islam.

Sementara 95\% responden yang menyatakan bahwa lembaga bank islam tidak mampu menjalankan fungsi sosialnya, yang terdiri dari sangat setuju $39 \%$ dan $56 \%$ yang setuju. Hal ini membuktikan masih buruknya tata kelola lembaga bank islam di Medan.

\section{5) Problem yang dirasakan nasabah \\ Tuduhan-tuduhan sinis terhadap nasabah selalu datang tanpa merasa ibah dengan nada}


menghina, setidak-tidaknya selalu memojokkan para nasabah dalam posisi dan proporsi rendah dan sangat tidak bersahaja. Selanjutnya ada lagi sebuah keputus-asaan dengan istilah "Meminjam uang pada rentenir lebih baik ketimbang meminjam ke bank islam". Demikianlah imbas kepentingan dan ketidak pedulian, yang sampai sekarang masih melekat di kalangan nasabah yang memahami persoalan prosedur dapat pinjaman pada lembaga bank islam. Lebih lanjut dapat diperhatikan beberapa kelemahankelemahan yang ada, yaitu; Sumber kelemahan utama adalah kurang berperannya fungsi dewan pengawas syariah.

Sumber kelemahan yang dimiliki peran dewan pengawas syariah, yaitu kurang berjalanya otoritas yang menjadi kewajiban bagi dewan syariah, hal ini didukung oleh responden diantaranya $24 \%$ sangat setuju, $41 \%$ setuju, 25\% kurang setuju dan $10 \%$ tidak setuju. Ternyata problem pada bank islam kurang berperannya stakeholder, yaitu tenaga yang profesional.

6) Peluang yang Mungkin Ditempuh

Konsep perbankan syariah berpeluang untuk merombak ketidak serasian antara pola konven dengan pola syariah, dan diharapkan perubahan yang harus dilakukan adalah dengan cara menyeleksi para pengelola khususnya dewan komisaris atau dewan direktur yang akan mengelola lembaga bank islam. Agar lembaga bank islam tidak lagi memiliki kesan sama saja dengan bank konven.

Ada beberapa hal yang perlu dianalisa tentang peluang yang mungkin ditempuh, bahwa bank islam harus mampu mengikis citra negatif dalam dilkalangan umat islam, ini dapat dilhat penelitian berikut; Peluang yang mungkin untuk merombak ketidak serasian antara pola konven dengan pola syariah terletak pada dewan komisaris bukan pada sistem.

Peluang yang mungkin untuk merombak ketidak serasian antara pola konven dengan pola syariah terletak pada dewan komisaris bukan pada sistem, hal ini responden memberikan jawaban sangat setuju ada $32 \%$, dan sebanyak $60 \%$ setuju, serta $8 \%$ kurang setuju.

\section{7) Langkah-langkah konkrit yang perlu dilakukan dalam menjalankan Sistem operasional bank islam}

Masyhudi

kepada mysharing.co, mengemukakan, bahwa kehadiran sejumlah produk bank syariah yang menawarkan 
pembiayaan tanpa agunan ratarata bergerak di usaha skala mikro. "Jumlah usaha mikro yang cukup banyak di Indonesia ini menggiurkan bank syariah sehingga ikut masuk ke pasar mikro, tapi dengan tidak adanya agunan sebenarnya cukup berisiko bagi bank syariah," Menurutnya, perbankan syariah harus punya sumber daya manusia yang mumpuni untuk melakukan review dan monitoring secara berkala terhadap nasabah. Di sisi lain, hal tersebut pun dapat membuat biaya operasional meningkat, karena dibutuhkann dana instan untuk biaya operasional pengawasan.

Kemudian yang terpenting bagaimana setiap lembaga perbankan syariah membuat langkah-langkah agar dapat tersedianya dana tanpa agunan. Maka untuk mendapatkan masa depan yang penuh dengan kesiapan diharuskan kepada setiap lembaga perbankan syariah harus mewujudkan langkah-langkah yang lebih elegan dan berpihak kepada kaum yang lemah karena tidak memiliki agunan. Salah satu ormas kota Medan, yaitu Pimpinan Daerah Muhammadiyah, menawarkan langkah-langkah, yaitu:

a. Dewan Syariah Nasional (DSN) dan Dewan Pengawas Syariah (DPS) harus mengeluarkan kebijakan yang sejalan dengan tujuan bank islam.

b. Bank Islam harus mengalokasikan untuk anggaran setiap tahun bersifat pinjaman di bawah 20 juta tanpa agunan.

c. Setiap pemberian pinjaman harus digunakan untuk kegiatan usaha yang bersifat produktif.

d. Pemberian pinjaman tanpa agunan dapat dilakukan oleh bank islam dengan ketentuan ada surat kuasa penjamin yang diberikan bukan surat agunan.

e. Peminjam harus orang yang dapat dipercaya, dan kepercayaan tersebut dapat diketahui melalui pemberi rekomendasi penjamin tersebut.

Melalui langkah-langkah yang lima ini, bila diterapkan akan menghasilkan perbankan syariah yang sangat diminati oleh masyarakat, dengan adanya minat masyarakat dapat menyakinkan bahwa posisi lembaga bank islam, memiliki nilai kepiawaian yang luar biasa. Tidak mungkin lagi akan muncul tudingan bank islam sama saja dengan bank konven. Untuk itu bagaimana pendapat responden tentang hal tersebut. Setiap Lembaga Perbankan Islam harus membuat program pembiayaan anggaran untuk peminjam tanpa agunan. 


\section{Peranan Penggunaan Agunan Di Bank Islam Hubungannya Dengan Sistem Operasional Perbankan Syariah Di Medan ( Selamat Pohan)}

\begin{abstract}
Kebutuhan dana untuk memulai aktivitas usaha sangat diharapkan oleh masyarakat, dan lembaga Perbankan Islam harus membuat program pembiayaan anggaran untuk peminjam tanpa agunan. Melalui jawaban responden atas pertanyaan yang diajukan, diantara responden yang menjawab sangat setuju ada $43 \%$, responden yang menjawab setuju ada $47 \%$. Hanya $10 \%$ saja responden yang menjawab kurang setuju dan menyatakan tidak setuju $0 \%$.
\end{abstract}

Sejalan dengan perkembangan zaman pengelola harus melakukan langkah-langkah konkrit secara gradual maupun secara akselerisasi, dengan harapan agar dunia tahu bahwa konsep Allah itu tidak ada yang salah, semuanya benar. Peminjam harus orang yang dapat dipercaya, dan kepercayaan tersebut dapat diketahui melalui pemberi rekomendasi penjamin tersebut. Berdasarkan data di atas, ini dapat terlihat melalui jawaban responden atas pertanyaan yang diajukan, diantara responden yang menjawab sangat setuju ada $65 \%$, responden yang menjawab setuju ada 29\%. Hanya 4\% saja responden yang menjawab kurang setuju dan menyatakan tidak setuju $2 \%$.

\section{F. Kesimpulan}

Berdasarkan hasil penelitian, pendapat nasabah dan ormas Islam di Medan tentang peranan penggunaan agunan yang diterapkan dalam sistem operasional perbankan syariah, kurang tepat karena tidak sesuai dengan tujuan bank islam jika harus di minta agunan dibawah pinjaman 20 juta-an. Dan sebagai solusi yang peneliti temukan adalah agar bank meminta surat kuasa penjamin pinjaman, bukan minta agunan.

Berdasarkan wawancara yang peneliti lakukan tentang kedudukan hukum agunan menjadi bagian sistem operasional perbankan syariah, itu tidak melanggar, karena untuk menjaga tingkat kehati-hatian. Maka merujuk pendapat para narasumber peneliti menyimpulkan boleh agunan diminta jika pinjaman di atas 20 juta-an. Karena jika di atas pinjaman 20 juta-an bank islam tidak memberlakukan pinjaman, dikhawatirkan bank bisa merugi, apabila rugi, maka masyarakat islam secara universal akan terugikan.

\section{G.Saran}

Adapun saran-saran yang dapat diajukan berdasarkan penelitian yang dilakukan adalah Pemberian pinjaman kepada nasabah yang mengajukan pembiayaan usaha produktif tidak memiliki agunan, jika hanya 20 juta-an kebawah sebaiknya dipermudah bukan dipersulit. 
Lembaga bank islam, harus mampu menjalankan tujuan bank islam, bukan hanya sekedar mengumpulkan uang nasabah, akan tetapi harus siap untuk juga untuk penyaluran yang bersifat ta'awun dan menarik minat nasabah untuk memamfaatkan eksistensi bank islam.

\section{Daftar Pustaka}

Adiwarman A. Karim, Ekonomi Islam Suatu Kajian Kontemporer. Jakarta: Gema Insani, 2001.

\section{Pendekatan}

Fiqih Terhadap Perbankan Syariah. Jakarta: Karim Business Consulting, 2002.

Arisson Hendry, et. Al., Perbankan Syariah Perspektif Praktisi. Jakarta: Muamalat Institute, 1999.

Dewan Syariah Nasional Majelis Ulama Indonesia, Himpunan Fatwa Dewan Syariah Nasional. MUI; Edisi Revisi. Jakarta: DSN-MUI, 2006.

Eriyanto, 2001. Analisis Wacana: Pengantar Analisis Teks Media. Yogyakarta: LKIS

IAIN Sumatera Utara, Pedoman Penulisan Proposal \& Disertasi PPS IAIN-SU. Program Pascasarjana IAINSU Medan, 2010.

Ibrahim Lubis, Ekonomi Islam Suatu

Pengantar-2. Jakarta: Kalam Mulia, 1995
Karnaen Perwataatmadja., Muhammad Syafi' I Antonio, Apa dan Bagaimana Bank Islam, cet.3. Yogyakarta: Dana Bhakti Prima Yasa, 1999.

Komaruddin., Yooke Tjuparmah S. Komaruddin. Kamus Istilah Karya Tulis Ilmiah. Jakarta: Bumi Aksara, 2000.

Muhammad, Manajemen Pembiayaan Bank Syariah. Yogyakarta: UPP AMP YMKN, 2005.

Muhammad Muslehuddin, Sistem Perbankan dalam Islam. Jakarta: Rineka Cipta, 1994.

Muhammad Nejatullah Siddiqi, Aspek-aspek Ekonomi Islam, terj. Dewi P. Restiana. Solo: Ramadhani, 1991.

Muhammad, Sistem dan Prosedur Operasional Bank Islam. Yogyakarta: Uli Press, 2000.

M. Syafi'i Antonio, Bank Syariah; Dari Teori ke Praktik. Jakarta: Gema Insani Press, 2001.

Neni Sri Imaniyati, Hukum Ekonomi dan Ekonomi Islam dalam perkembangan. Bandung: Mandar Maju, 2002.

Undang-Undang Republik Indonesia Nomor 21 tahun 2008 tentang perbankan syariah. 2008.

Zainul Arifin, Memahami Bank syariah Lingkup, Peluang, Tantangan dan Prospek. Cet. 3. Jakarta: Alva Bet, 2000. 
Peranan Penggunaan Agunan Di Bank Islam Hubungannya Dengan Sistem Operasional Perbankan Syariah Di Medan ( Selamat Pohan) 